Finisterra, XXXVII, 74, 2002, pp. 33-54

\title{
INUNDAÇÕES NA CIDADE DE LISBOA DURANTE O SÉCULO XX E SEUS FACTORES AGRAVANTES ${ }^{1}$
}

\author{
Pedro Elias Oliveira ${ }^{2}$ \\ CATARINA RAMOS ${ }^{3}$
}

\begin{abstract}
Resumo - Na cidade de Lisboa ocorrem, com bastante frequência, inundações que não se relacionam com o transbordo de cursos de água a céu aberto e que se podem classificar de urbanas, por ocorrerem em tecido urbano impermeabilizado, e rápidas, pela velocidade de formação e propagação. O presente estudo abrangeu o período compreendido entre 1918/19 e 1997/98, no qual se registaram 420 ocorrências. As inundações são mais frequentes no Outono (principalmente em Novembro) mas, a partir dos anos 70, diminuíram consideravelmente, ao mesmo tempo que aumentaram o volume total das chuvadas e a precipitação máxima horária que as desencadeiam. A caracterização dos aspectos físicos da cidade (relevo e bacias de drenagem) e da malha urbana (tipos de nós e vias), bem como a relação desta com a antiga rede de drenagem, permitiu destacar os factores agravantes das inundações. A partir da análise factorial efectuou-se a tipologia dos locais inundados, bem como a avaliação da respectiva perigosidade, baseada na frequência de ocorrência das inundações. Os locais inundados mais perigosos localizam-se, principalmente, na Frente Ribeirinha, nos sectores terminais das antigas linhas de água, em praças ou ruas receptoras do escoamento, dispostos perpendicularmente às antigas linhas de água, e em locais em que existem barreiras artificiais ou micro-depressões resultantes da artificialização da superfície topográfica. Outros «locais-críticos» que subsistem por toda a cidade devem-se a problemas de entupimento ou deficiência de vazão do sistema de drenagem artificial da cidade, muitas vezes agravados pela urbanização e impermeabilização de novas áreas.
\end{abstract}

Palavras-chave : Lisboa, perigosidade, inundações urbanas, factores agravantes.

1 Este artigo baseia-se na investigação desenvolvida na dissertação de mestrado de Pedro Elias Oliveira (OlIVEIRA, 2002), orientada por Catarina Ramos.

2 Professor do Ensino Secundário na Escola Secundária Pedro Nunes. E-mail: franzini57@ hotmail.com

3 Investigadora do Centro de Estudos Geográficos e Prof. ${ }^{a}$ Auxiliar do Departamento de Geografia da FLUL. E-mail: cramos@mail.doc.fl.ul.pt 


\begin{abstract}
INUNDATIONS IN LISBON DURING THE 20TH CENTURY AND THEIR URBAN AND PHYSICAL CAUSES. Lisbon often suffers inundations, which must be classified as urban inundations, because the flooded areas involved are impermeable due to urban development. These inundations are not related to the overflow of watercourses, but can be classified as flash inundations because of the speed with which they form and spread. The present study covers a time period from 1918/19 to $1997 / 98$, during which 420 occurrences were recorded in two leading daily newspapers, "O Século» and «Diário de Notícias». The research based on these newspapers takes into account daily rainfalls above $10 \mathrm{l} / \mathrm{m}^{2}$ recorded by the Instituto Geofísico Infante D. Luís, as well as daily rainfall below this level but that have also caused inundations. The analysis of the frequency and evolution of these inundations has showed that they occur more often during the autumn (specially in November) and that from the seventies onwards, they have decreased considerably, while at the same time the total rainfall volume has increased, as well as the maximum hourly rainfall that bring them about. Fieldwork was very important in the definition of flooded sites. Research was carried out to specify the physical factors (relief and drainage basins) and urban network (squares and streets). The relationship between these urban factors and the old drainage network was also taken into account in order to distinguish increasing inundation factors. Apart from the description of the physical characteristics of these sites, they were also typified through factor analysis. A hazard factor was attributed to each site based on inundation frequency. The most endangered areas and sites are located mainly in the "Frente Ribeirinha» (along the river bank) built upon the terminal sectors of the natural watercourses, which consists of the receptor streets and receptor squares of the flow. These streets and squares lie perpendicular to the ancient watercourses, and in places where artificial barriers and micro depressions exist. The latter result from the artificial surface of the riverside embankment. Other critical sites exist throughout the town mainly because of obstruction problems or deficient drainage systems, often aggravated, by newly built up impervious areas.
\end{abstract} factors.

Key words : Lisbon, natural hazard, urban inundations, physical and urban

\title{
I. INTRODUÇÃO
}

Em Portugal, segundo CosTa (1986), ocorrem três grandes tipos de inundações: as devidas às cheias dos grandes rios, que se formam ao fim de vários dias ou semanas de chuvas prolongadas; as devidas às cheias dos pequenos cursos de água, que se formam ao fim de algumas horas de chuva intensa; e as inundações urbanas, que se podem formar em algumas dezenas de minutos, aquando de fortes chuvadas cujas consequências são agravadas pela impermeabilização dos terrenos.

Assim, como nem todas as inundações são devidas a cheias, e como os antigos cursos de água, que drenavam a área hoje ocupada pela cidade de Lisboa, estão canalizados subterraneamente ou entulhados, utilizar-se-á, no presente artigo, o termo inundação e não o de cheia, dado que o fenómeno em estudo não tem origem na subida do nível de um curso de água e seu transbordo, mas sim 
no alagamento de determinadas áreas, devido à impermeabilização da superfície e à incapacidade de escoamento do sistema de drenagem de águas pluviais da cidade.

Tal como refere ReBelo (1997), as inundações urbanas (por ocorrerem em solo urbano, impermeabilizado na sua quase totalidade), são consideradas rápidas, por se formarem em poucas horas ou até minutos. No caso de Lisboa, este tipo de inundações tem aspectos muito particulares. Em geral, os volumes de água implicados são pequenos, embora possam interromper a circulação do metropolitano ou o trânsito automóvel e alagar os andares térreos residenciais ou de estabelecimentos comerciais, em vários locais da cidade, provocando um certo caos na actividade urbana, por desorganizarem as acessibilidades internas e por afectarem a dinâmica comercial da cidade. Em norma, não provocam vítimas mortais: nas piores inundações que afectaram a região de Lisboa no século XX (Novembro de 1967), dos cerca de 700 mortos registados apenas 4 faleceram no interior da cidade.

Mas, nas inundações de grande magnitude, enquanto nos locais deprimidos para onde converge o escoamento, como por exemplo em Xabregas ou em Alcântara, a altura das águas pode ultrapassar 1m; nos locais mais declivosos, como por exemplo, nas ruas de São Bento e do Arco do Carvalhão, a velocidade das águas atinge valores consideráveis, podendo arrancar as pedras das calçadas e até arrastar automóveis.

TElHAdo (1998) salienta que as áreas da cidade mais sensíveis às inundações são as que se encontram a baixa altitude (Frente Ribeirinha e fundos de vale), onde a influência das marés, assim como o assoreamento dos colectores, provocam o mau funcionamento do sistema de drenagem artificial da cidade; as atravessadas por linhas de água (parcial ou totalmente canalizadas subterraneamente ou entulhadas); as de planeamento deficiente, ou seja, os locais onde a dimensão dos novos colectores se encontra desajustado face às reais necessidades dos volumes escoados; as não sujeitas a limpezas, desentupimentos e desassoreamento das valetas, sumidoros ou esgotos, como seria desejável; as coincidentes com obras de arte, do tipo passagem inferior (caso dos túneis), por entupimento dos sumidouros e deficiências técnicas do equipamento.

Neste artigo, os autores propõem-se definir, dentro da cidade de Lisboa, a evolução das inundações que a afectaram durante o século XX (entre 1918 e 1998); os locais inundados e a respectiva perigosidade (baseada na frequência de ocorrência do fenómeno em cada um deles); as características da morfologia da cidade (nomeadamente o relevo e a antiga rede de drenagem) e da malha urbana (em especial a posição das praças e ruas face ao sentido do escoamento) por serem factores que afectam, localmente, as inundações.

O levantamento das inundações baseou-se numa pesquisa na imprensa diária, principalmente nas notícias dos jornais "O Século" e "Diário de Notícias». Esta pesquisa foi complementada por uma lista dos dias cuja precipitação diária foi igual ou superior a $10 \mathrm{l} / \mathrm{m}^{2}$, valor considerado significativo como base de pesquisa. Esta selecção de datas foi efectuada a partir dos registos da preci- 
pitação referentes à estação climatológica de Lisboa/Instituto Geofísico. Além destes dias, foram consultados os calendários das precipitações intensas publicados em Oliveira (1942), bem como a base de dados do Departamento de Climatologia do IGIDL (dados não publicados). O tratamento estatístico descritivo da informação (análise univariada e bivariada) foi efectuado a partir dos programas Excel®, Andad® e Statistica ${ }^{\circledR}$. Na análise factorial (Componentes Principais, Análise de Correspondências Binárias, Análise de Correspondências Múltiplas) utilizou-se o Andad®. Toda a informação espacial, locais inundados, características físicas da cidade e da malha urbana, foi tratada e cartografada, utilizando Sistemas de Informação Geográfica, a partir do programa ArcView ${ }^{\circledR}$.

\section{VARIAÇÃO TEMPORAL DAS INUNDAÇÕES ENTRE 1918 E 1998}

A análise da evolução do número de inundações foi organizada por ano climatológico, a fim de se poderem comparar com os parâmetros pluviométricos. Nos 80 anos estudados, ocorreram 420 inundações em 418 dias; ou seja, em média, cerca de 5 inundações por ano, o que revela a grande frequência do fenómeno na cidade. Em 45\% dos anos, a cidade foi afectada por 2 a 4 inundações, destacando-se o ano de 1965-66 com 20 ocorrências. Apenas em 3 anos não se registaram inundações em Lisboa: 1979-80, 1991-92 e 1994-95. A variação interanual do número de inundações é muito irregular. O período em estudo pode ser dividido em três sub-períodos (fig. 1): o $1 .^{\circ}$ de 1918-19 a 1934-35, o $2 .^{\circ}$ de $1935-36$ a $1969-70$ e o $3 .^{\circ}$ de $1970-71$ a $1997-98$. Nos sub-períodos I e III ocorreram em média 3 inundações por ano, com uma amplitude de variação

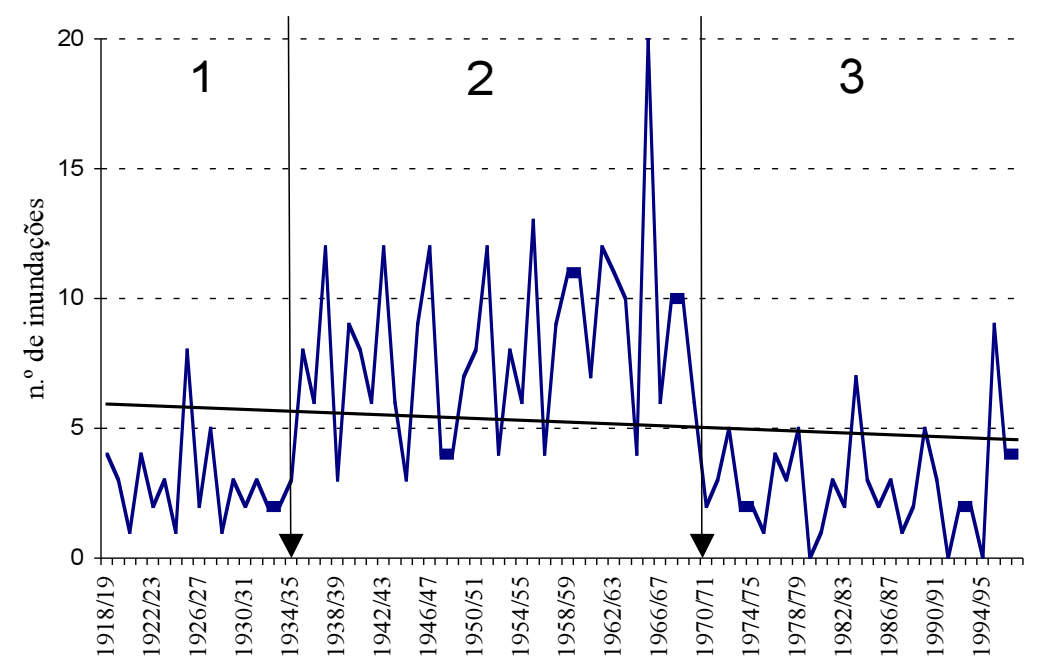

Fig. 1 - Tendência evolutiva do número de inundações por ano na cidade de Lisboa, entre 1918-19 e 1997-98.

Fig. 1 - Annual evolution of the inundations in Lisbon, between 1918-19 and 1997-98. 
entre 0 e 7; no sub-período II, a frequência foi mais elevada: 8 inundações em média por ano, com uma amplitude de variação entre 3 e 20. Este sub-período coincidiu com uma série de anos chuvosos, dos quais se destacam os compreendidos entre 1962-63 e 1968-69, em que o total anual em Lisboa ultrapassou $1000 \mathrm{l} / \mathrm{m}^{2}$. O já citado ano de 1965-66, com o maior número de inundações (20), foi também o mais chuvoso, com $12141 / \mathrm{m}^{2}$. No cômputo geral, entre $1918 \mathrm{e}$ 1998, houve uma tendência para a diminuição do número de inundações em Lisboa, fundamentalmente a partir de 1970-71, mantendo-se, todavia, com uma frequência elevada para um meio urbano ( 3 por ano).

Um outro aspecto interessante é o de que o Outono (Setembro, Outubro e Novembro) é a estação do ano mais problemática para a cidade com $41 \%$ do total das inundações, logo seguida do Inverno (Dezembro, Janeiro e Fevereiro) com 37\%. A Primavera (Março, Abril e Maio) situa-se ligeiramente abaixo da metade do valor do Outono e ligeiramente acima da metade do valor do Inverno.

Depois do período estival, as inundações aumentam entre a $1 .^{\mathrm{a}}$ quinzena de Setembro e a $1 .^{\text {a }}$ de Novembro (fig. 2); ou seja, de 7 (1,7\%) para 44 ocorrências $(10,5 \%)$ descendo posteriormente de uma forma gradual e algo irregular até à $1 .^{\mathrm{a}}$ quinzena de Junho (fig. 2). Entre a 2. ${ }^{\mathrm{a}}$ quinzena de Junho e a 2. ${ }^{\mathrm{a}}$ de Agosto as ocorrências são insignificantes. O período mais crítico para a cidade concentrase entre a $2 .^{\mathrm{a}}$ quinzena de Outubro e a $1 .^{\mathrm{a}}$ de Dezembro, em que ocorreram $35 \%$ do total das inundações. Novembro poderá ainda tornar-se um mês mais perigoso por, ao contrário da tendência geral detectada no período estudado (Oliveira, 2002), ser o único mês em que se tem vindo a verificar um aumento das inundações em Lisboa.

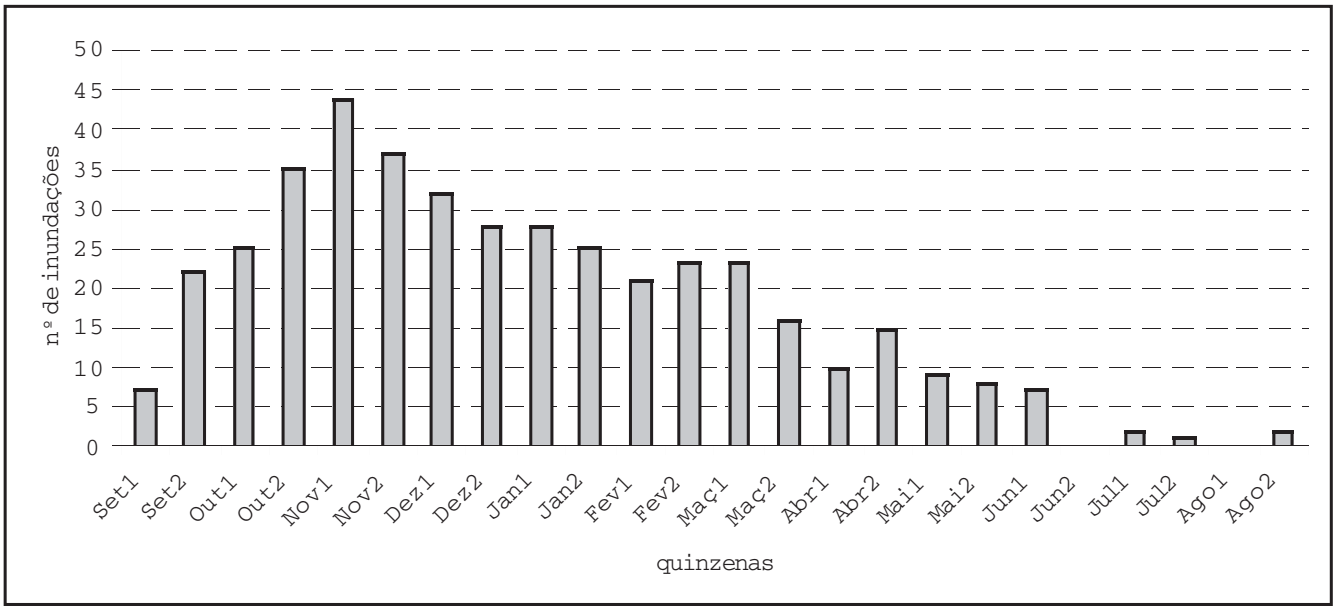

Fig. 2 - Número de inundações por quinzena na cidade de Lisboa, entre 1918-19 e 1997-98.

Fig. 2 -Number of inundations in Lisbon per two weeks, between 1918-19 and 1997-98. 


\section{ANÁLISE DE ALGUMAS CARACTERÍSTICAS DAS CHUVADAS QUE DESENCADEARAM AS INUNDAÇÕES}

As chuvadas que estiveram na origem das inundações foram caracterizadas através de quatro parâmetros distintos: duração da chuvada, valor total da chuvada, precipitação máxima horária e hora de ocorrência desta, definidos a partir do valor da precipitação ocorrida em cada hora específica $(0-1 \mathrm{~h}, 1-2 \mathrm{~h}, \ldots$, 23-24h), referente ao período exacto em que o episódio ocorreu. A duração da chuvada, bem como o respectivo valor total, foram obtidos a partir do somatório do número de períodos de uma hora seguidos, com precipitação igual ou superior a $11 / \mathrm{m}^{2}$. Estes dados, registados nos Anais do IGIDL, apenas começam a ser publicados a partir de 1930 (inclusive), pelo que foi reduzido, neste ponto, o período em estudo de 80 para 68 anos, o qual abrange 383 inundações, ou seja, $91 \%$ do total.

A grande maioria dos episódios de inundação, cerca de 84\% (324 ocorrências), tiveram origem em chuvadas de duração $\leq 6$ horas (fig. 3A), situando-se as mais frequentes (43\%) entre 2 e 3 horas. O valor máximo ocorreu em Janeiro de 1958 (24h de duração).

O valor total da chuvada foi inferior a $40 \mathrm{l} / \mathrm{m}^{2}$ em $92 \%$ das ocorrências (fig. 3B), registando a classe entre 10 e $201 / \mathrm{m}^{2}$, por si só, $38 \%$ dos episódios. O valor máximo ocorreu em 19 de Novembro de 1983 e foi de 95,11/ $\mathrm{m}^{2}$ (numa chuvada que durou $12 \mathrm{~h}$ ).
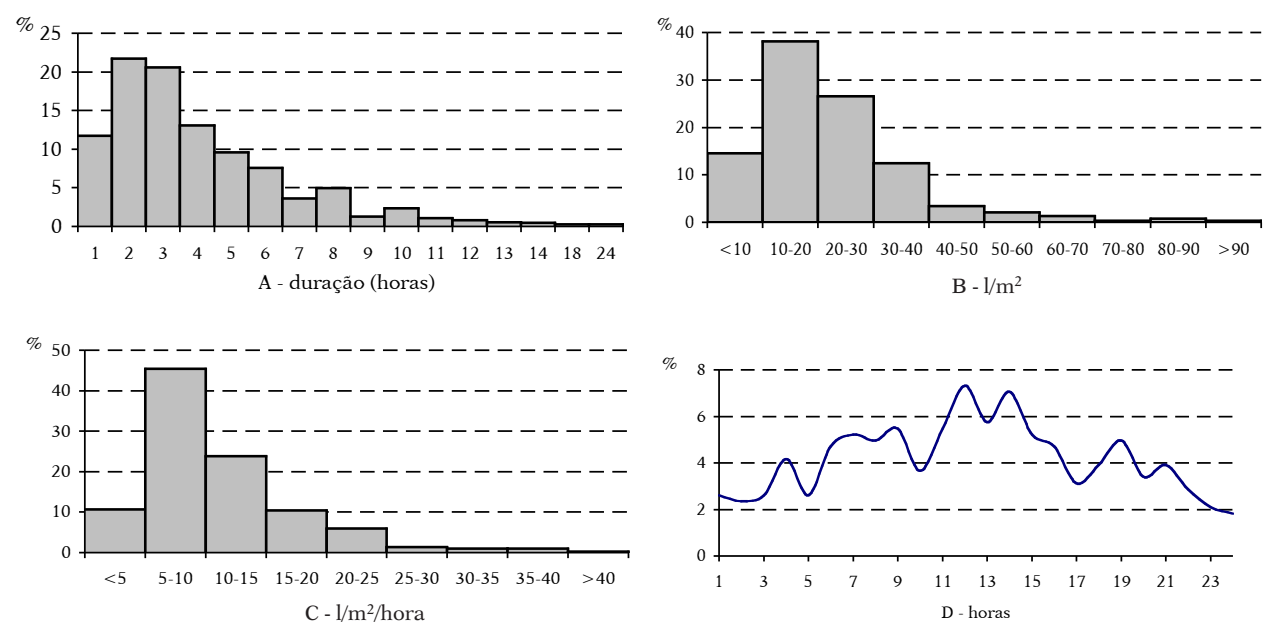

Fig. 3 - Frequência relativa da duração das chuvadas (A), do valor total das chuvadas (B), da precipitação máxima horária (C) e da hora de ocorrência desta (D), entre 1930-31 e 1997-98.

Fig. 3 - Frequency of rainfall duration $(A)$, total rainfall $(B)$, hourly maximum rainfall (C), hour of occurrence (D), between 1930-31 and 1997-98. 
A figura 3C revela que cerca de $2 / 3$ das ocorrências (69\%) atingiram uma precipitação máxima horária entre 5 e $15 \mathrm{l} / \mathrm{m}^{2} / \mathrm{h}$, situando-se a classe mais frequente ( $45 \%$ do total) entre 5 e $10 \mathrm{l} / \mathrm{m}^{2} / \mathrm{h}$. O valor máximo registou-se em 18 de Outubro de 1997, tendo atingido $42,61 / \mathrm{m}^{2} / \mathrm{h}$.

As precipitações máximas horárias, relativas aos episódios de inundação, ocorrem com maior frequência (72\%) durante o dia, entre as $6 \mathrm{~h}$ e as $19 \mathrm{~h}$, atingindo o máximo de frequência (20\%) no período mais quente, ou seja, entre as 12 e as 14 h (fig. 3D).

No quadro I, estão representados os episódios em que se registaram os valores mais elevados dos três parâmetros pluviométricos, a saber: valor total da chuvada $>501 / \mathrm{m}^{2}$, duração superior a $4 \mathrm{~h}$ e precipitação máxima horária $>151 / \mathrm{m}^{2}$. Destaca-se o facto de três dos doze episódios terem ocorrido em 1997, último ano do período em estudo.

A análise das tendências evolutivas efectuada aos três parâmetros pluviométricos (Oliveira, 2002) mostrou que, enquanto na duração das chuvadas houve uma tendência para a estabilização, já no valor total das chuvadas e na precipitação máxima horária houve um claro incremento. Daqui se pode concluir que, presentemente, para que ocorra um episódio de inundação na

Quadro I - Inundações com origem em precipitações de grande magnitude na cidade de Lisboa.

Table I - Inundation events in Lisbon due to the highest rainfall duration (> 4h), total rainfall $\left(>50 \mathrm{l} / \mathrm{m}^{2}\right)$ and hourly maximum rainfall $\left(>15 \mathrm{l} / \mathrm{m}^{2}\right)$.

\begin{tabular}{|c|c|c|c|c|c|}
\hline $\begin{array}{l}\text { Data } \\
\text { da } \\
\text { ocorrência }\end{array}$ & $\begin{array}{c}\text { Valor Total } \\
(1 / \mathrm{m})\end{array}$ & $\begin{array}{c}\text { Duração } \\
\text { (h) }\end{array}$ & $\begin{array}{l}\text { P. Máx. } \\
\text { Horária } \\
(1 / \mathrm{m} / \mathrm{h})\end{array}$ & $\begin{array}{l}\text { P. Máx. Horária } \\
\text { em relação } \\
\text { ao valor total }\end{array}$ & $\begin{array}{r}\text { Precipitação } \\
\text { média horária } \\
\text { (\%) }(1 / \mathrm{m})\end{array}$ \\
\hline $23 / 09 / 1943$ & 62,4 & 11 & 23,7 & 38 & 5,7 \\
\hline $22 / 01 / 1959$ & 55,8 & 11 & 18,8 & 32 & 5,3 \\
\hline $10 / 10 / 1962$ & 63,7 & 5 & 30,2 & 47 & 12,7 \\
\hline $14 / 10 / 1965$ & 53,6 & 8 & 24,5 & 46 & 6,7 \\
\hline $25 / 11 / 1967$ & 88,6 & 14 & 26,1 & 29 & 6,3 \\
\hline $09 / 01 / 1969$ & 77,0 & 13 & 17,5 & 23 & 5,9 \\
\hline $31 / 01 / 1972$ & 51,0 & 8 & 15,8 & 31 & 6,4 \\
\hline $10 / 02 / 1979$ & 67,8 & 11 & 38,1 & 56 & 6,2 \\
\hline $19 / 11 / 1983$ & 95,1 & 12 & 35,1 & 37 & 7,9 \\
\hline $18 / 05 / 1997$ & 52,5 & 6 & 28,8 & 55 & 8,8 \\
\hline $18 / 10 / 1997$ & 84,9 & 5 & 42,6 & 50 & 17,0 \\
\hline $02 / 11 / 1997$ & 87,8 & 8 & 36,1 & 41 & 11,0 \\
\hline
\end{tabular}

cidade é necessária uma maior quantidade de precipitação, quer dos valores acumulados (valor total da chuvada), quer da precipitação máxima horária. Este facto pode ser devido, entre outros aspectos, à melhoria gradual do sistema de drenagem de águas residuais/pluviais da cidade e à diminuição de lixos, terras e entulhos que entopem as sarjetas e colectores. 


\section{OS LOCAIS INUNDADOS}

A área estudada refere-se ao conjunto das bacias de drenagem, cujas superfícies se encontram totalmente envolvidas pelo limite administrativo da cidade, à excepção da bacia da R. ${ }^{\mathrm{a}}$ de Alcântara, que extravasa esses limites, na sua secção noroeste. Por tal motivo, a totalidade da área da bacia da R. ${ }^{a}$ de Alcântara foi apenas considerada, na análise das bacias e redes de drenagem, para efeitos de cálculo dos respectivos parâmetros morfométricos.

Foram assim excluídas deste estudo as seguintes áreas: vertente ocidental da Serra de Monsanto, que pende para o vale da R. ${ }^{a}$ de Algés; as secções das bacias que correm para norte em direcção à R. ${ }^{a}$ de Odivelas, nomeadamente as áreas da Colina do Sol, Pontinha e Calçada de Carriche; todo o nordeste da cidade a norte da Avenida Marechal Gomes da Costa, por ter uma ocupação urbana relativamente recente.

Em 1918, a quase totalidade da área em estudo, já se encontrava construída. Apenas estavam por urbanizar: o troço da Avenida Almirante Reis a norte da Praça do Chile (Bairro dos Actores), a Avenida Gago Coutinho e o Bairro de Alvalade.

A lista dos locais inundados foi elaborada a fim de se obter uma informação o mais rigorosa possível, extirpando repetições ou imprecisões de localização, tendo-se recorrido ao levantamento de campo para a resolução de certas dúvidas, sempre que se revelou necessário. Foram também tidas em consideração as mudanças de nome das ruas e uniformizada a informação tendo por base as actuais designações. Verificou-se, ainda, que em cerca de $10 \%$ das notícias relativas às 420 inundações registadas, não é referida a localização dos sítios inundados. Depois de efectuadas todas estas correcções, obtiveram-se 1077 locais inundados em Lisboa. Todavia, a análise posterior destes 1077 locais revelou que cerca de metade apenas foi inundado uma ou duas vezes, ao longo dos 80 anos em estudo. A fim de eliminar possíveis situações aleatórias de alagamento, e como o objectivo era o de definir os locais mais sensíveis às inundações, foram seleccionados os afectados mais de duas vezes, tendo-se obtido 505 locais.

$\mathrm{Na}$ cartografia dos locais inundados, nos casos em que a inundação atingiu de igual forma toda a via ou nos casos de dúvida, considerou-se o ponto médio, quer do eixo (rua ou avenida) quer do nó (praça ou largo).

A figura 4 mostra que os locais mais frequentemente inundados se distribuem principalmente: pela Frente Ribeirinha (Alcântara, Avenida 24 de Julho, ruas da Boavista e de São Paulo, Cais do Sodré, Terreiro do Paço, Santa Apolónia, Caminhos de Ferro e Xabregas); pela Baixa, estendendo-se pelas Avenidas Almirante Reis e da Liberdade; e a partir de Sete Rios pela Estrada de Benfica e ao longo do eixo Rego - Campo Grande - Lumiar. Cerca de 1/4 dos locais foi inundado 10 ou mais vezes (quadro II), ou seja, uma vez ou mais em cada oito anos.

A classe mais elevada (total de inundações $\geq 40$ ) representa os locais que foram inundados em média 1 vez em cada 2 anos ou em todos os anos, o que corresponde a $4 \%$ do total. Estes locais são os de maior perigosidade da cidade 


\section{1}

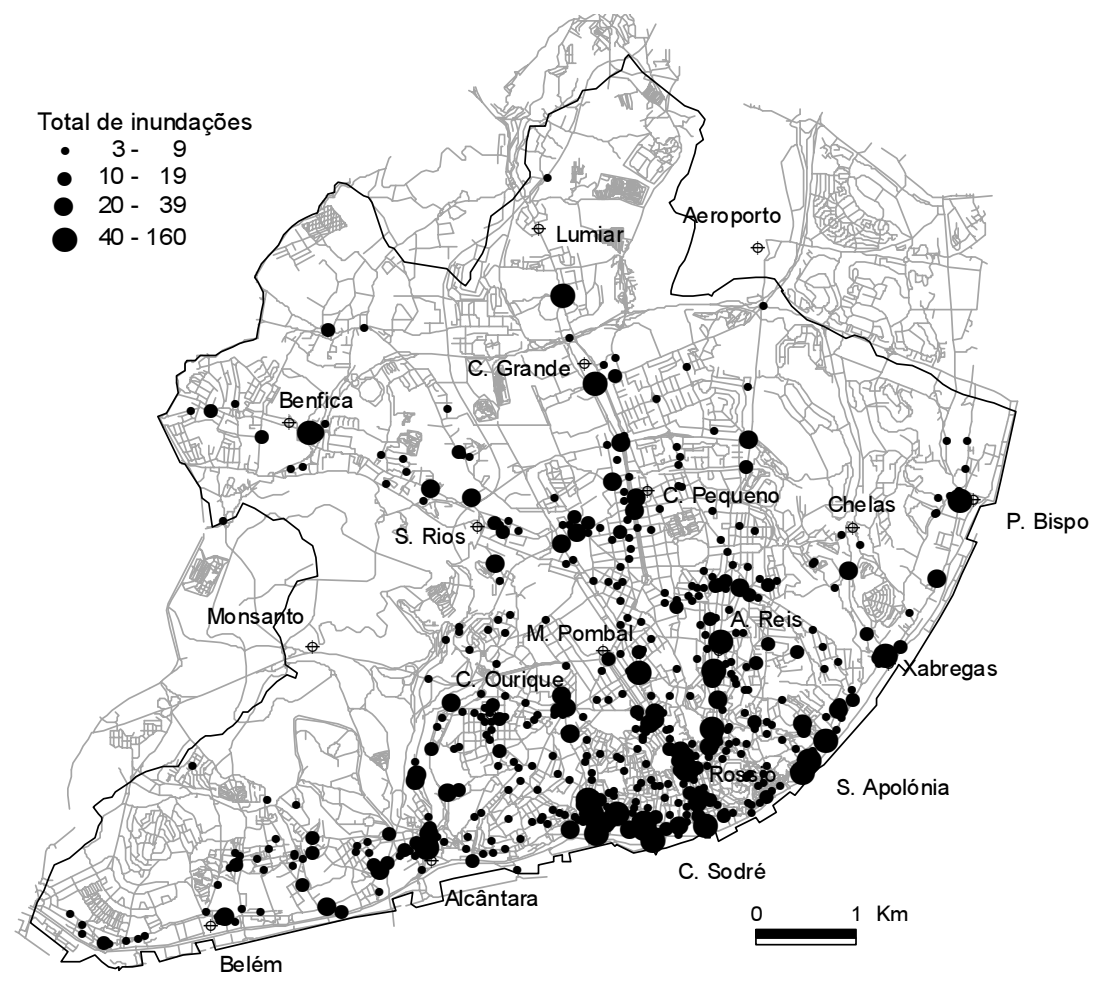

Fig. 4 - Locais com mais de 2 episódios de inundação na cidade de Lisboa, entre 1918-19 e 1997-98.

Fig. 4 -Sites in Lisbon with more than 2 inundation events, between 1918-19 and 1997-98.

(fig. 5). Os quatro locais mais críticos, ou seja, aqueles em que ocorreram 1 ou mais inundações por ano, encontram-se na Frente Ribeirinha: Rua dos Caminhos de Ferro a Santa Apolónia (155 inundações), Avenida 24 de Julho (142), Xabregas (123) e Rua de São Paulo (90).

\section{OS FACTORES AGRAVANTES DAS INUNDAÇÕES: CARACTERÍSTICAS FÍSICAS E DA MALHA URBANA}

Com o objectivo de compreender quais os factores agravantes em cada local inundado, procedeu-se à definição das características físicas e da malha urbana da cidade. Dos 505 locais, 17 foram excluídos por serem demasiado abrangentes (bairros ou áreas) não permitindo a necessária análise de pormenor. A análise dos factores agravantes incide, por isso, sobre uma amostragem de 488 locais ( $97 \%$ do total). 
Quadro II - Classes de locais segundo a frequência de inundação (1918-19 a 1997-98).

Table II - Inundation frequency classes (1918-19 to 1997-98).

\begin{tabular}{|c|c|c|c|c|}
\hline $\begin{array}{c}\text { Total de } \\
\text { Inundações }\end{array}$ & $\begin{array}{c}\text { N. } \cong \text { de } \\
\text { locais }\end{array}$ & $\%$ & Frequência de ocorrên & $\begin{array}{c}\text { Nóa de inundaçõe } \\
\text { por década }\end{array}$ \\
\hline $3-9$ & 357 & 74 & Reduzida & 0,4 a 1,2 \\
$10-19$ & 73 & 15 & Média & 1,3 a 2,4 \\
$20-39$ & 38 & 8 & Elevada & 2,5 a 4,9 \\
$\geq 40$ & 20 & 4 & Muito elevada & $\geq 5$ \\
\hline
\end{tabular}

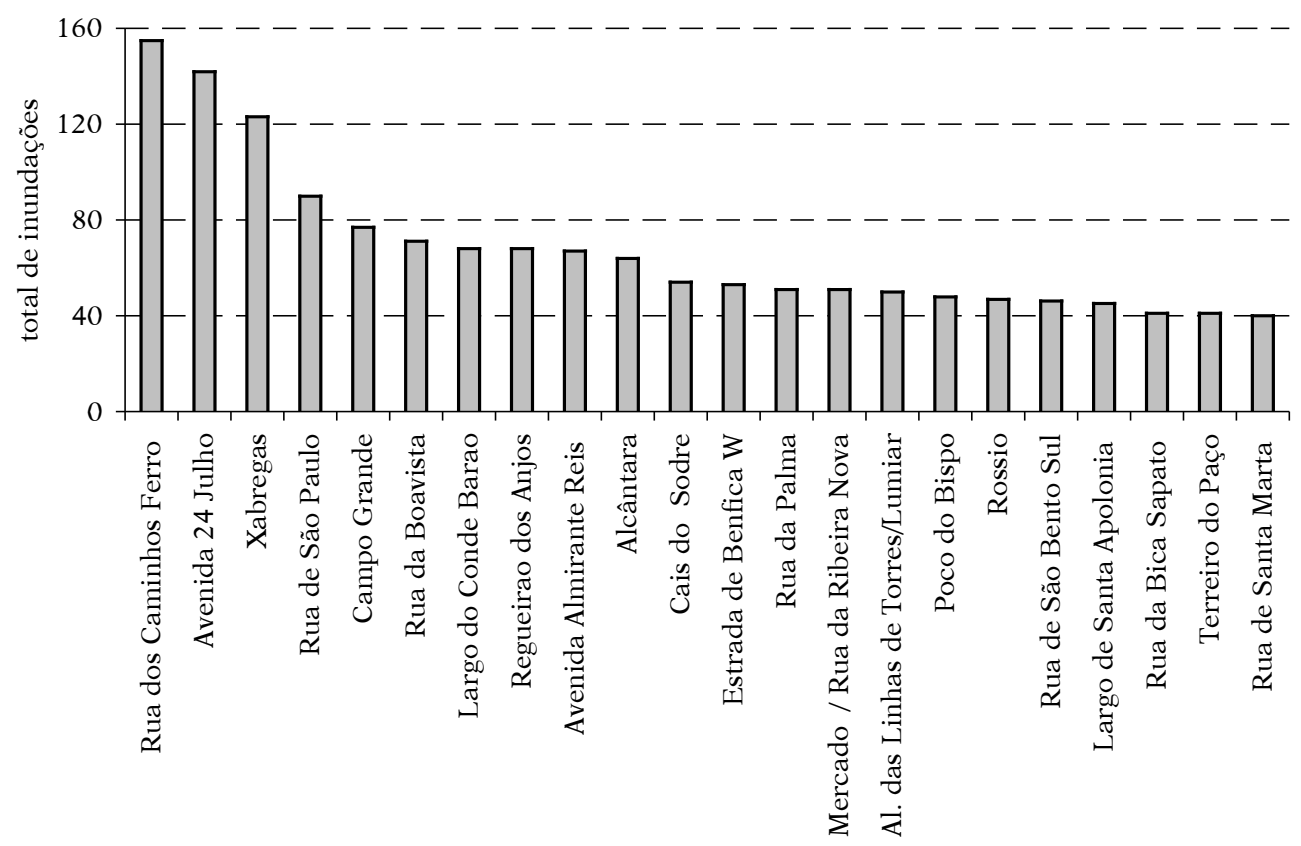

Fig. 5 - Número de inundações nos locais de maior perigosidade da cidade de Lisboa, entre 1918-19 e 1997-98.

Fig. 5 -Number of inundations in the most dangerous sites in Lisbon, between 1918-19 and 1997-98.

\section{Unidades de relevo (declives e posição topográfica): sua influência nas inundações}

Definiram-se as unidades de relevo, dando especial realce aos declives e posição topográfica, uma vez que dos primeiros depende a velocidade de escoamento e da segunda depende a dispersão ou concentração das águas. 
A cidade de Lisboa estende-se por três unidades de relevo distintas: a Área Planáltica, a Área Acidentada e a Frente Ribeirinha (fig. 6). A Área Planáltica abrange o Centro, Noroeste e Nordeste da cidade. A sua altitude varia entre um pouco mais de $100 \mathrm{~m}$ e $80 \mathrm{~m}$, inclinando no sentido N-S. Nela predominam os fracos declives (entre 0 e $5^{\circ}$ ) e vales muito abertos ou incipientes. Sob a designação de Área Acidentada foram agrupados três sectores distintos do ponto de vista morfológico: a vertente oriental da Serra de Monsanto, a Costa da Luz Bairro da Cortegaça (elemento da grande costeira de Frielas) e a vertente ribeirinha, que liga a Área Planáltica à Frente Ribeirinha. Na Área Acidentada, embora predominem os declives moderados a fortes, apresentando a maior parte das vertentes voltadas ao rio declives $>10^{\circ}$, é possível distinguir uma dissimetria W-E, sendo o sector oriental (a NE do Vale de Chelas) o menos declivoso (declives $<5^{\circ}$ ). A Frente Ribeirinha é uma faixa aplanada, em grande parte resultante de aterros (TELLES, 1997), compreendida entre o rio Tejo e a curva de nível dos 5m, embora se estenda, em alguns locais, até à curva dos 10m. Locali-

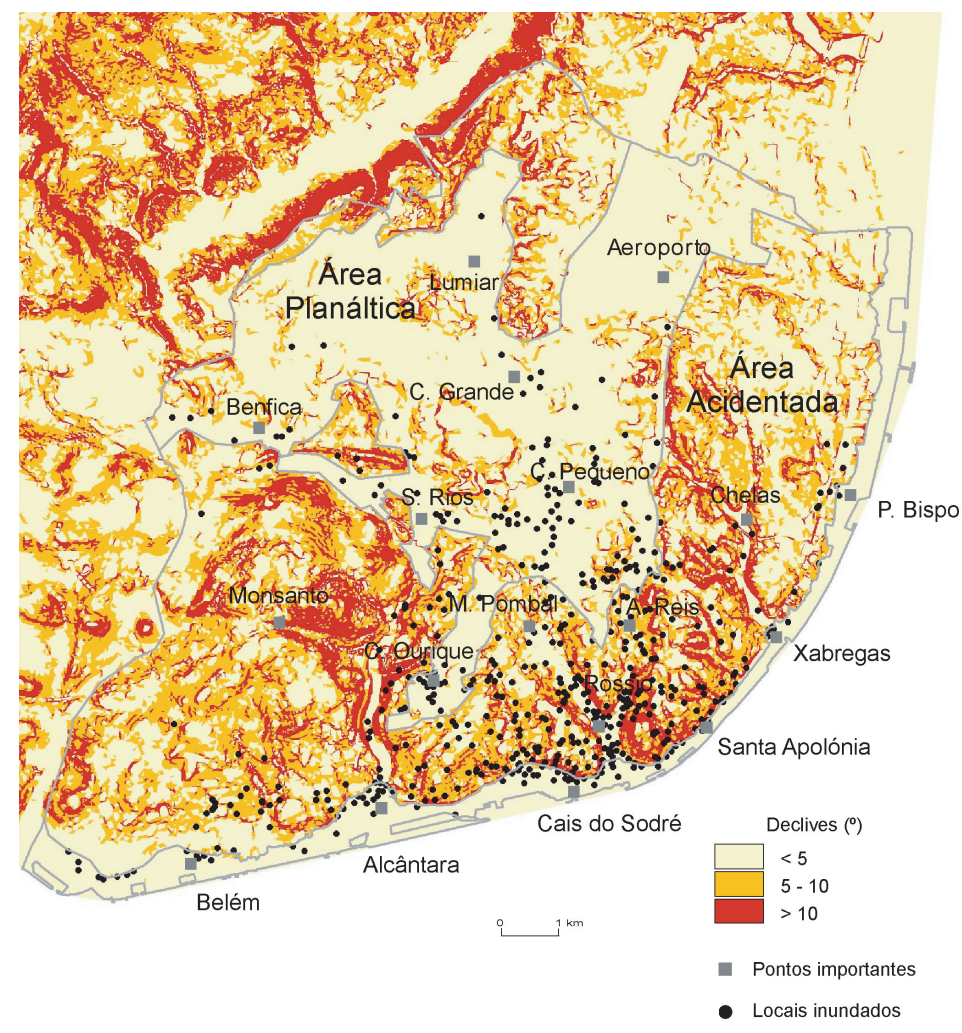

Fig. 6 - Posição dos locais inundados em cada unidade de relevo da cidade de Lisboa (1918-19 a 1997-98).

Fig. 6-The relief units and the flooded sites in Lisbon (1918-19 to 1997-98). 
zada no extremo sul e sueste da cidade, estende-se de Algés a Moscavide e apresenta uma largura variável, que ultrapassa as duas centenas de metros em alguns sectores. Apesar de aplanada, a Frente Ribeirinha possui pequenos desníveis, que originam micro-formas de relevo (micro-interflúvios e talvegues).

$\mathrm{Na}$ figura 6, os locais inundados encontram-se distribuídos pelas três unidades de relevo da cidade. $61 \%$ localizam-se na Área Acidentada, $24 \%$ na Área Planáltica e $16 \%$ na Frente Ribeirinha. A Área Acidentada sobressai como a mais afectada pelas inundações devido à sua maior extensão e pelo facto de nela se encontrarem os entalhes mais profundos (factor de convergência de águas). Se examinarmos os locais inundados relativamente à sua posição topográfica (interflúvio, vertente ou fundo de vale), verifica-se que os que se posicionam em fundo de vale são os mais frequentes (48\%), seguidos pelos que estão nas vertentes (43\%). Os locais posicionados em interflúvios apresentam frequências muito baixas, por serem áreas dispersoras de águas. Mais de metade $(57 \%)$ dos locais inundados localizam-se em áreas pouco declivosas (declive $<5^{\circ}$ ), ou seja, nos fundos de vale da Área Planáltica e da Área Acidentada bem como na Frente Ribeirinha.

\section{Bacias-vertente e antiga rede de drenagem da cidade}

Actualmente, embora sejam raros os cursos de água subaéreos que atravessam sectores muito restritos da cidade, a análise da antiga rede de drenagem é importante, dado que os antigos talvegues se conservam, apesar da urbanização, definindo áreas deprimidas onde se concentra o escoamento aquando das grandes chuvadas.

A delimitação das bacias de drenagem, sobre as quais foi construída a cidade de Lisboa, foi efectuada sobre o mapa das curvas de nível, tendo este sido obtido a partir da vectorização de isolinhas existentes no verso da Carta do Concelho de Lisboa 1/10 000. Pelo facto das bacias estarem inseridas em ambiente urbano, não foram considerados o coberto vegetal e a litologia devido à impermeabilização dos terrenos. Os parâmetros escolhidos (quadro 3) pretendem evidenciar as características geométricas, hidrográficas e morfológicas de cada uma das bacias de drenagem. Estas características são importantes pela implicação que têm na quantidade de água que pode atingir os antigos talvegues e na forma como o escoamento se concentra ao longo deles.

Das 23 bacias definidas (quadro III e fig. 7), a maioria (61\%) não atinge $1 \mathrm{~km}^{2}$ de área. De todas elas destaca-se a da R. ${ }^{a}$ de Alcântara por ser a maior, ultrapassando $40 \mathrm{~km}^{2}$, logo seguida pelas de Chelas $\left(7 \mathrm{~km}^{2}\right)$ e da Baixa $\left(6 \mathrm{~km}^{2}\right)$. As maiores bacias caracterizam-se por apresentarem um maior desenvolvimento da rede de drenagem, atingindo um número elevado de linhas de água e uma hierarquização superior. Assim, as bacias da R. ${ }^{a}$ de Alcântara, da Baixa e de Chelas atingem o número de ordem 4 e possuem, respectivamente, 84, 38 e 34 afluentes. 
Quadro III - Agrupamento das bacias de drenagem com base em parâmetros morfométricos semelhantes.

Table III - Classification of the Lisbon drainage basins by similar morphometric parameters.

\begin{tabular}{|c|ccc|ccc|cc|}
\hline & \multicolumn{3}{|c|}{ Geometria } & \multicolumn{3}{c|}{ Rede de drenagem } & \multicolumn{2}{c|}{ Relevo } \\
\hline \multirow{3}{*}{ Bacia } & Área & Perímetro & Forma & Magnitude & Hierarquia & DH & Desnível & Declive \\
& $\left(\mathrm{km}^{2}\right)$ & $(\mathrm{km})$ & $($ Gravelius $)$ & $($ Shreve $)$ & $($ Strahler $)$ & $\left(\mathrm{l} . \mathrm{a} / \mathrm{km}^{2}\right)$ & $(\mathrm{m})$ & $(\mathrm{m} / \mathrm{hm})$ \\
\hline
\end{tabular}

\begin{tabular}{|l|l|lll|lll|ll|}
\hline $\mathbf{A}$ & RIB. DE AlCÂNTARA & $\mathbf{4 0 , 9 3}$ & $\mathbf{4 3 , 1 7}$ & $\mathbf{1 , 8 9}$ & $\mathbf{8 4}$ & $\mathbf{4}$ & $\mathbf{2 , 1}$ & $\mathbf{2 3 3}$ & $\mathbf{2 , 3}$ \\
\hline
\end{tabular}

\begin{tabular}{|c|c|rrr|rrr|rr|}
\hline \multirow{4}{*}{ B } & BAIXA & $\mathbf{6 , 2 0}$ & $\mathbf{1 3 , 0 2}$ & $\mathbf{1 , 4 6}$ & 38 & 4 & $\mathbf{6 , 1}$ & $\mathbf{1 2 0}$ & $\mathbf{3 , 7}$ \\
& S. BENTO & $\mathbf{1 , 8 8}$ & $\mathbf{6 , 2 1}$ & $\mathbf{1 , 2 6}$ & 18 & 3 & $\mathbf{9 , 6}$ & $\mathbf{1 0 5}$ & $\mathbf{4 , 7}$ \\
& CHELAS & $\mathbf{7 , 4 3}$ & $\mathbf{1 5 , 2 3}$ & $\mathbf{1 , 5 5}$ & $\mathbf{3 4}$ & $\mathbf{4}$ & $\mathbf{4 , 6}$ & $\mathbf{1 1 0}$ & $\mathbf{2 , 2}$ \\
\hline
\end{tabular}

\begin{tabular}{|c|c|rrr|rrr|rr|}
\hline & RESTELO & $\mathbf{1 , 7 9}$ & $\mathbf{7 , 0 1}$ & $\mathbf{1 , 4 6}$ & $\mathbf{3}$ & $\mathbf{2}$ & $\mathbf{1 , 7}$ & $\mathbf{1 2 0}$ & $\mathbf{4 , 7}$ \\
& JERÓNIMOS & $\mathbf{2 , 0 7}$ & $\mathbf{7 , 9 5}$ & $\mathbf{1 , 5 5}$ & $\mathbf{4}$ & $\mathbf{2}$ & $\mathbf{1 , 9}$ & $\mathbf{1 7 0}$ & $\mathbf{6 , 6}$ \\
& RIO SECO & $\mathbf{2 , 9 3}$ & $\mathbf{7 , 9 3}$ & $\mathbf{1 , 3 0}$ & $\mathbf{7}$ & $\mathbf{3}$ & $\mathbf{2 , 4}$ & $\mathbf{1 8 0}$ & $\mathbf{6 , 7}$ \\
& POÇO BISPO & $\mathbf{2 , 9 0}$ & $\mathbf{7 , 8 9}$ & $\mathbf{1 , 2 9}$ & $\mathbf{5}$ & $\mathbf{2}$ & $\mathbf{1 , 7}$ & $\mathbf{8 5}$ & $\mathbf{4 , 0}$ \\
\hline
\end{tabular}

\begin{tabular}{|c|c|ccc|ccc|cc|}
\hline \multirow{2}{*}{ D } & VALE S. ANTÓNIO & $\mathbf{0 , 5 5}$ & $\mathbf{3 , 5 8}$ & $\mathbf{1 , 3 6}$ & $\mathbf{5}$ & $\mathbf{2}$ & $\mathbf{9 , 0}$ & $\mathbf{1 0 0}$ & $\mathbf{7 , 8}$ \\
& VALE ESCURO & $\mathbf{0 , 9 8}$ & $\mathbf{4 , 9 2}$ & $\mathbf{1 , 4 0}$ & $\mathbf{6}$ & $\mathbf{2}$ & $\mathbf{6 , 1}$ & $\mathbf{1 1 0}$ & $\mathbf{5 , 9}$ \\
\hline
\end{tabular}

\begin{tabular}{|c|c|rll|rrr|rr|}
\hline INFANTE SANTO & $\mathbf{0 , 6 9}$ & $\mathbf{4 , 4 7}$ & $\mathbf{1 , 5 0}$ & $\mathbf{3}$ & $\mathbf{2}$ & $\mathbf{4 , 3}$ & $\mathbf{1 0 0}$ & $\mathbf{6 , 0}$ \\
LUÍS CAMÕES & $\mathbf{0 , 5 0}$ & $\mathbf{3 , 5 0}$ & $\mathbf{1 , 3 8}$ & $\mathbf{2}$ & $\mathbf{2}$ & $\mathbf{4 , 1}$ & $\mathbf{7 5}$ & $\mathbf{6 , 3}$ \\
DUQUE DE LAFÕES & $\mathbf{0 , 7 3}$ & $\mathbf{3 , 3 5}$ & $\mathbf{1 , 1 1}$ & $\mathbf{2}$ & $\mathbf{2}$ & $\mathbf{2 , 8}$ & $\mathbf{6 0}$ & $\mathbf{7 , 7}$ \\
BEATO & $\mathbf{0 , 6 0}$ & $\mathbf{4 , 2 0}$ & $\mathbf{1 , 5 1}$ & $\mathbf{2}$ & $\mathbf{2}$ & $\mathbf{3 , 3}$ & $\mathbf{7 0}$ & $\mathbf{4 , 5}$ \\
AJUDA & $\mathbf{0 , 8 4}$ & $\mathbf{5 , 7 0}$ & $\mathbf{1 , 7 4}$ & $\mathbf{1}$ & $\mathbf{1}$ & $\mathbf{1 , 2}$ & $\mathbf{1 4 0}$ & $\mathbf{7 , 3}$ \\
$\mathbf{E}$ & $\mathbf{0 , 2 7}$ & $\mathbf{2 , 3 0}$ & $\mathbf{1 , 2 3}$ & $\mathbf{1}$ & $\mathbf{1}$ & $\mathbf{3 , 4}$ & $\mathbf{8 0}$ & $\mathbf{1 2 , 0}$ \\
JANELAS VERDES & $\mathbf{0 , 3 9}$ & $\mathbf{3 , 1 0}$ & $\mathbf{1 , 4 0}$ & $\mathbf{2}$ & $\mathbf{2}$ & $\mathbf{5 , 1}$ & $\mathbf{8 0}$ & $\mathbf{1 1 , 0}$ \\
LAPA & $\mathbf{0 , 1 2}$ & $\mathbf{2 , 0 0}$ & $\mathbf{1 , 6 0}$ & $\mathbf{1}$ & $\mathbf{1}$ & $\mathbf{8 , 6}$ & $\mathbf{7 0}$ & $\mathbf{8 , 3}$ \\
BICA & $\mathbf{0 , 2 8}$ & $\mathbf{2 , 9 0}$ & $\mathbf{1 , 5 2}$ & $\mathbf{3}$ & $\mathbf{2}$ & $\mathbf{1 0 , 8}$ & $\mathbf{7 5}$ & $\mathbf{6 , 7}$ \\
FLORES & $\mathbf{0 , 1 5}$ & $\mathbf{1 , 8 9}$ & $\mathbf{1 , 3 6}$ & $\mathbf{1}$ & $\mathbf{1}$ & $\mathbf{6 , 5}$ & $\mathbf{5 0}$ & $\mathbf{7 , 5}$ \\
CHIADO & $\mathbf{0 , 3 2}$ & $\mathbf{2 , 7 1}$ & $\mathbf{1 , 3 3}$ & $\mathbf{2}$ & $\mathbf{2}$ & $\mathbf{6 , 3}$ & $\mathbf{9 5}$ & $\mathbf{1 4 , 7}$ \\
ALFAMA & $\mathbf{0 , 4 0}$ & $\mathbf{2 , 8 0}$ & $\mathbf{1 , 2 3}$ & $\mathbf{0}$ & $\mathbf{0}$ & $\mathbf{0 , 0}$ & $\mathbf{5 5}$ & $\mathbf{7 , 8}$ \\
SANTO AMARO & $\mathbf{0 , 3 2}$ & $\mathbf{2 , 4 0}$ & $\mathbf{1 , 1 8}$ & $\mathbf{0}$ & $\mathbf{0}$ & $\mathbf{0 , 0}$ & $\mathbf{8 0}$ & $\mathbf{1 4 , 2}$ \\
\hline SANTA CLARA
\end{tabular}

As bacias de média e grande dimensão (à escala da cidade), apesar dos respectivos desníveis serem maiores, apresentam declives menos vigorosos. As bacias de menor dimensão têm, pelo contrário, desníveis inferiores, mas maiores declives. É de salientar que cerca de metade das bacias atinge um desnível $\geq 100 \mathrm{~m}$, destacando-se os da R. ${ }^{a}$ de Alcântara (233m), Rio Seco (180m), Jerónimos (170m), Ajuda (140m), Restelo e Baixa (120m). Relativamente ao declive, 
quase metade das bacias apresentam valores $>7 \mathrm{~m} / \mathrm{hm}$, sendo as mais declivosas a de Alfama $(14,7 \mathrm{~m} / \mathrm{hm})$, Santa Clara $(14,2 \mathrm{~m} / \mathrm{hm})$, Janelas Verdes $(12 \mathrm{~m} / \mathrm{hm})$ e Lapa $(11 \mathrm{~m} / \mathrm{hm})$. A maioria das bacias (20 em 23) é compacta, por apresentar um índice de Gravelius $(\mathrm{Kc})<1,6$. As bacias de dimensão inferior apresentam, geralmente, índices menores, o que revela a sua maior apetência, quanto à forma, na produção de "pontas de escoamento». Nas de Duque de Lafões $(\mathrm{Kc}=1,1)$ e Santa Clara $(\mathrm{Kc}=1,2)$ é facilmente perceptível a tendência que as respectivas formas têm para se aproximar do círculo.

A análise factorial em componentes principais, aplicada à matriz dos dados relativos aos parâmetros morfométricos, mostrou que as bacias de grande dimensão e fraco declive se associam às de elevados valores do índice de Gravelius, desnível, magnitude e hierarquia. Pelo contrário, os valores reduzidos destes quatro parâmetros surgem associados às bacias de superfície reduzida e declive vigoroso. Esta técnica permitiu seleccionar como parâmetros mais importantes: área, forma, desnível, declive das bacias, hierarquia e magnitude da antiga rede de drenagem. Com base nas correlações obtidas entre os parâmetros morfométricos e na análise factorial, estabeleceram-se os cinco grupos de bacias representados no quadro III e figura 7, e já explicitados em OliveIRA (2002).

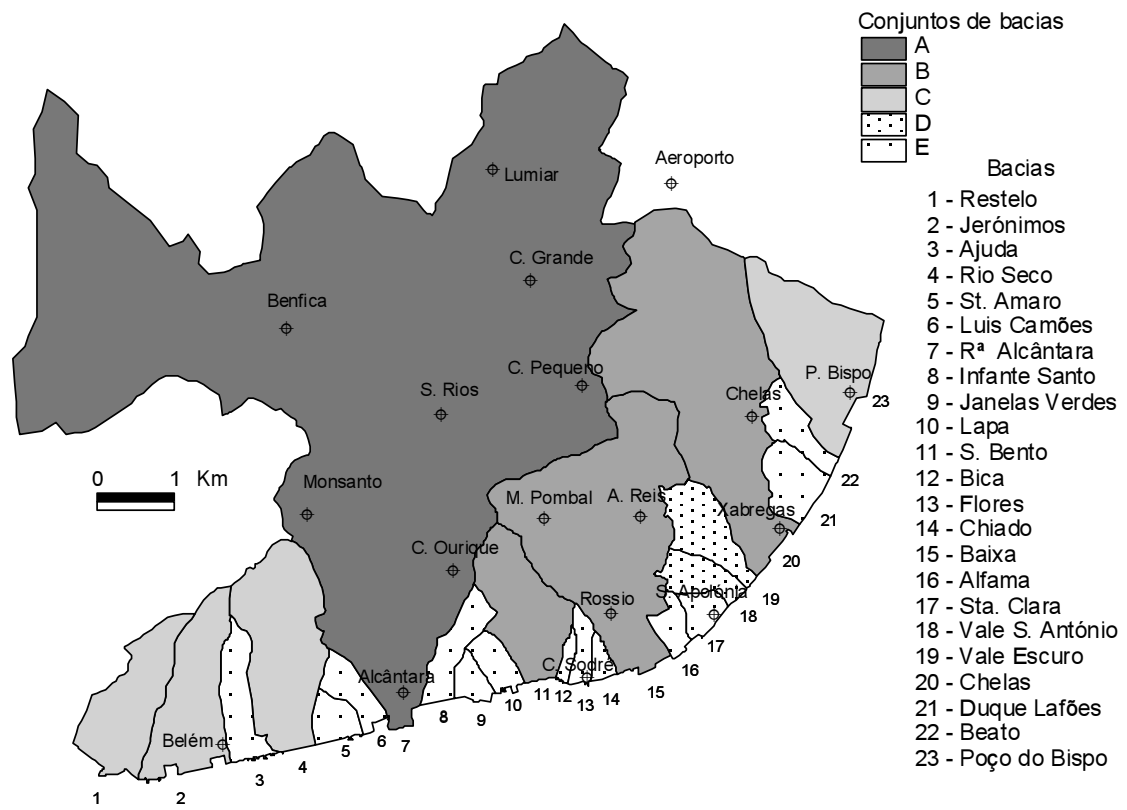

Fig. 7 - Conjuntos de bacias de drenagem da cidade de Lisboa com características morfométricas semelhantes (ver legenda no Quadro III).

Fig. 7-Classification of the Lisbon drainage basins by similar morphometric parameters. 
Desta análise conclui-se que a perigosidade das bacias de maior dimensão, ligada aos maiores escoamentos produzidos, é devida à área de drenagem, hierarquização e magnitude da rede de drenagem e ao desnivelamento; enquanto a perigosidade das bacias de dimensão mais reduzida é devida fundamentalmente ao forte declive, o que implica uma maior rapidez de escoamento.

$\mathrm{Na}$ maioria das bacias de drenagem, principalmente nas de maior dimensão, é perfeitamente perceptível o grande número de locais inundados alinhados ao longo da antiga rede de drenagem (fig. 8). De facto, cerca de metade (48\%) dos locais inundados encontram-se sobre as antigas linhas de água. Na bacia da R. ${ }^{a}$ da Alcântara, estes locais estendem-se, não só ao longo da secção inferior, mas também das três principais secções superiores, principalmente na vinda do extremo norte da cidade pelo «eixo» Lumiar - Campo Grande - Av. de Berna até à Praça de Espanha e também na que vem pela Estrada de Benfica. Nos vales da

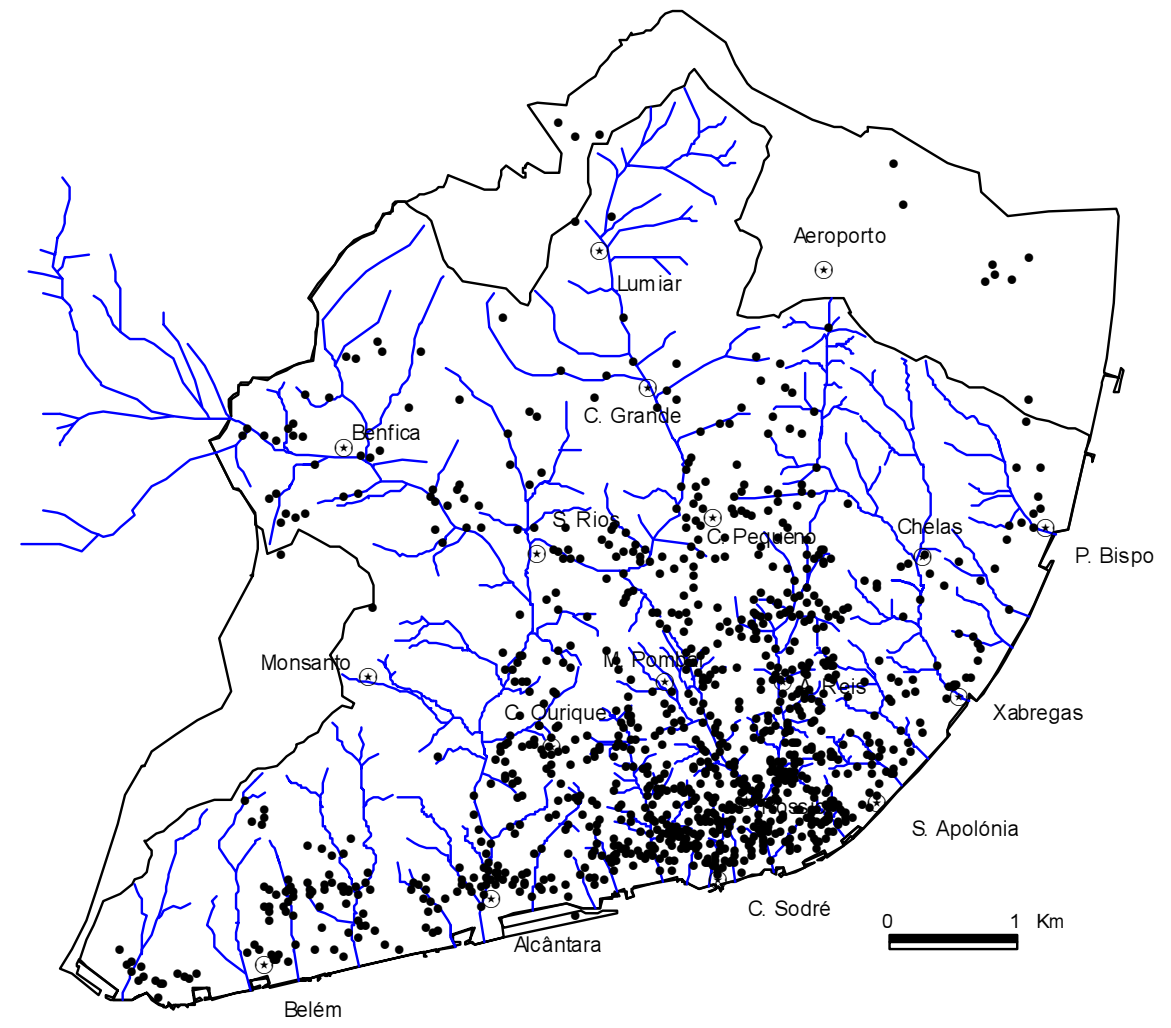

Fig. 8 - Posição dos locais inundados relativamente às antigas linhas de água da cidade de Lisboa (1918-19 a 1997-98).

Fig. 8- The ancient watercourses and the flooded sites in Lisbon (1918-19 to 1997-98). 
Baixa, os locais inundados estendem-se pela secção inferior (Baixa Pombalina) e pelas secções superiores (Av. da Liberdade e Rua da Palma - Av. Almirante Reis). $\mathrm{O}$ alinhamento ao longo do «eixo» central do vale de $\mathrm{S}$. Bento é também visível.

\section{A influência da malha urbana nas inundações}

Como toda a área em estudo se encontra inserida num meio urbano, a malha urbana torna-se tão importante, numa situação de inundação, como os vários parâmetros físicos. Foram, por isso, seleccionados os parâmetros pertencentes à malha urbana, que podem agravar as inundações. A análise incidiu sobre as características individuais de cada tipo de eixos (avenidas e ruas) e nós (praças e largos), tendo-se elaborado a sua classificação, quer em relação ao sentido do escoamento das águas superficiais quer à sua posição face às antigas linhas de água (quadro IV). Da totalidade dos locais inundados, $86 \%$ localizam-se em ruas/avenidas e os restantes $14 \%$ em praças/largos, devido ao facto de existir um maior número de eixos do que de nós.

Quadro IV - Tipologia das características da malha urbana em relação ao escoamento e frequência absoluta dos locais inundados em cada uma delas.

Table IV-Urban elements typology related to the water flow and absolute frequency of the flooded sites in each one of them.

\begin{tabular}{|c|l|c|}
\hline \multicolumn{2}{|c|}{ Tipologia dos elementos da malha urbaña de Loca } \\
inundados
\end{tabular}




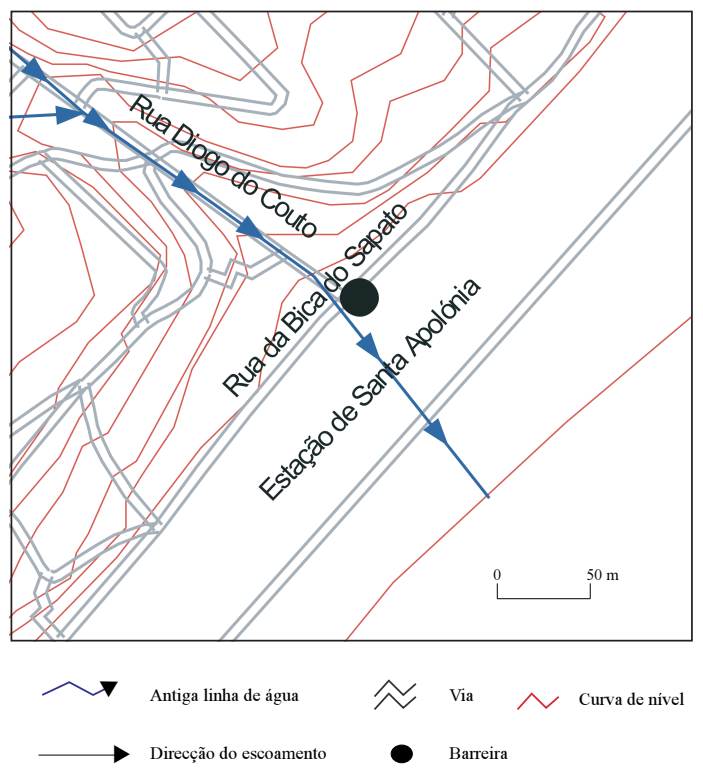

Fig. 9 - Influência dos elementos da malha urbana (eixos e barreiras) nos locais afectados pelas inundações.

Fig. 9 -Example of urban elements influence on the flooded sites: streets and artificial barriers.

Quando se sobrepõem as ruas e as praças à topografia, verifica-se que, numa situação de chuva intensa, as vias podem funcionar como canalizadoras ou receptoras do escoamento superficial. Os cruzamentos de vias podem ser locais sensíveis quando correspondem à intercepção de duas vias inundáveis; daí que as vias com encruzilhadas tenham sido consideradas separadamente. Uma via é canalizadora, quando apenas orienta o fluxo de água entre dois pontos, sendo geralmente curta e sem ruas confluentes (ex: Rua Diogo do Couto, fig. 9); é receptora, quando a ela afluem outras ruas canalizadoras ou receptoras, nunca apresentando encruzilhadas (ex: Rua da Bica do Sapato, fig. 9). Assim, $37 \%$ dos locais inundados localizam-se em cruzamentos, logo seguidos das ruas receptoras $(28 \%)$ e canalizadoras $(22 \%)$.

As praças e largos podem, também ser divididos em três tipos: emissores, quando funcionam apenas como áreas de divergência de águas (ex: Largo da Graça, Praça do Saldanha); encaminhadores, quando recebem ruas canalizadoras ou receptoras e enviam águas geralmente para um eixo (Marquês de Pombal, Rato, fig.10); receptores, quando a eles apenas afluem ruas e se encontram localizados na Frente Ribeirinha, cujos fracos declives facilitam aí uma paragem ou travagem do fluxo de água (ex: Largo de Alcântara, Praça do Terreiro do Paço). Os mais frequentemente inundados (8\% do total dos locais) 
são os encaminhadores, que exercem um «efeito de funil» sobre os fluxos (fig. 10), seguidos dos receptores (5\%), localizados na Frente Ribeirinha, na sua maioria na desembocadura dos grandes vales. Os largos emissores representam apenas $1 \%$ dos locais inundados, porque são sítios de divergência de águas.

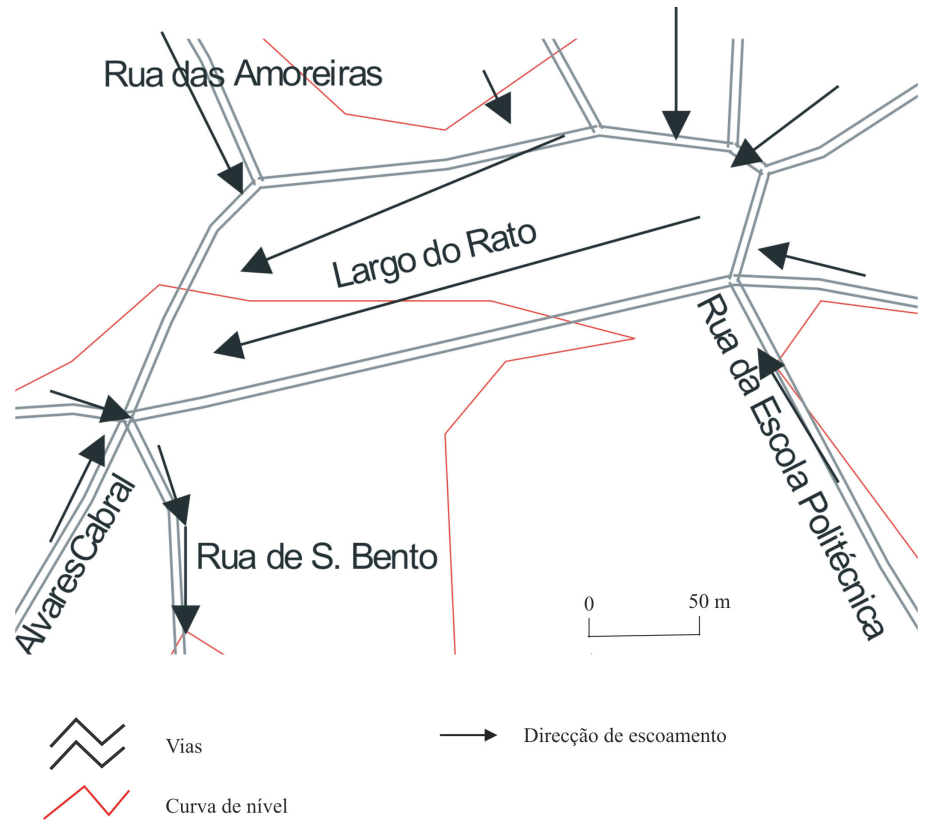

Fig.10 - Influência dos elementos da malha urbana (praça encaminhadora) nos locais afectados pelas inundações.

Fig. 10-Example of urban elements influence on the flooded sites: a canalized square.

Verificou-se, igualmente, qual a posição das ruas/avenidas face às antigas linhas de água (paralela, perpendicular ou oblíqua). Cerca de metade (48\%) são paralelas, localizando-se a maioria em fundos de vale (ex: Rua Diogo do Couto, fig. 9). Este facto confirma que a perigosidade é maior nas artérias paralelas às antigas linhas de água, devido à coincidência de direcção da linha de água e do eixo urbano, que incrementa e acelera os fluxos de água em situações de inundação, e também por receberem lateralmente as águas das ruas que descem as vertentes, como acontece com a Rua das Portas de Santo Antão. Assim, algumas das largas avenidas de Lisboa foram abertas paralelamente a antigas linhas de água, aproveitando fundos de vale largos e planos, mas «fugindo» à posição mais deprimida (talvegue). Assim, por exemplo, a Avenida da Liberdade estende-se paralelamente às ruas de Santa Marta, S. José e Portas de Santo Antão, situadas no talvegue do antigo Vale Verde. 
Foram ainda detectados 40 locais (8\% do total) artificialmente deprimidos (túneis, viadutos, ou micro-depressões em determinados sectores das ruas), resultantes da artificialização da superfície topográfica, onde a água se acumula e que têm problemas crónicos de inundação, como é o caso dos túneis do Campo Grande e Campo Pequeno. A estes locais juntam-se mais 17, em que muros e prédios funcionam como barreiras à circulação das águas agravando os efeitos das inundações locais, como por exemplo, o entroncamento da Rua da Bica do Sapato com a Rua Diogo do Couto, a qual se localiza em frente à ala norte da estação de Santa Apolónia (fig. 9).

\section{TIPOLOGIA DOS LOCAIS AFECTADOS PELAS INUNDAÇÕES}

A relação entre os locais com diferentes graus de perigosidade (definida a partir da frequência de ocorrência das inundações em cada local) e os factores agravantes, anteriormente explicitados, foi feita a partir da análise factorial de correspondências. A matriz ficou composta por 488 linhas, referentes a cada um dos locais inundados, e 37 colunas: 31 referentes a modalidades activas (características físicas e da malha urbana) e 6 a modalidades suplementares, referentes a seis classes de frequência de ocorrência de inundações. Resultou uma variabilidade total explicada em 27 eixos, em que os 6 primeiros explicam cerca de $45 \%$ da variabilidade. A maioria das 18 modalidades referentes às características físicas surgem explicadas nos 3 primeiros eixos e a maioria das 13 variáveis referentes à malha urbana surgem explicadas nos eixos posteriores. As modalidades referentes aos factores físicos são explicadas nas primeiras projecções: as referentes à posição topográfica são explicadas, na totalidade, até ao eixo 4 e as relativas à antiga rede de drenagem são explicadas até ao eixo 5 . A maioria das variáveis antrópicas são explicadas nos eixos 5 e 6, excepto duas modalidades relativas à posição das vias face às antigas linhas de água (paralela e perpendicular) que são explicadas pelos eixos 3 e 4, respectivamente.

Na tentativa de uniformizar e sintetizar a informação associaram-se os grupos que apresentam uma ou mais modalidades iguais, tendo-se obtido 5 tipos de locais, diferenciados essencialmente pelo declive, que separa o primeiro tipo (declive médio a forte) dos restantes (declive fraco), e pela posição topográfica, a qual diferencia os 4 tipos seguintes (quadro V).

Como conclusão, poderemos afirmar que os locais situados nas vertentes da Área Acidentada da cidade são os que apresentam a menor frequência de inundações (tipo 1). Estes locais, com declives médios a fortes, são lugares de passagem da água em direcção às áreas mais baixas da cidade, principalmente ao longo das ruas canalizadoras. No extremo oposto, estão os locais de frequência muito elevada de inundações que apresentam as características do último tipo (5). De facto, todos os locais inundados localizados na unidade de relevo Frente Ribeirinha são perigosos, independentemente do micro-relevo que esta possa ter (talvegue ou micro-interflúvio). No entanto, essa perigosidade é refor- 
Quadro V - Tipologia dos locais afectados pelas inundações na cidade de Lisboa.

Table V-Flooded sites typology in Lisbon.

\begin{tabular}{|c|c|c|c|}
\hline Tipos de locais & $\begin{array}{c}\text { Frequência } \\
\text { de inundações }\end{array}$ & $\begin{array}{c}\text { Outras características } \\
\text { fisicas }\end{array}$ & $\begin{array}{c}\text { Caracteristicas da malha } \\
\text { urbana }\end{array}$ \\
\hline $\begin{array}{l}1 \text { - Vertentes da Área } \\
\text { Acidentada da cidade }\end{array}$ & Reduzida & Declives médios e fortes & $\begin{array}{l}\text { Ruas canalizadoras } \\
\text { Via oblíqua à antiga } \\
\text { linha de água } \\
\text { Viadutos } \\
\text { Túneis }\end{array}$ \\
\hline $\begin{array}{c}2 \text { - Interflúvios } \\
\text { e vertentes da Área } \\
\text { Planáltica }\end{array}$ & $\begin{array}{l}\text { Médio- } \\
\text {-reduzida }\end{array}$ & 一 & Cruzamentos de ruas \\
\hline $\begin{array}{l}3 \text { - Interflúvios da } \\
\text { Área Acidentada }\end{array}$ & - & - & Praças emissoras \\
\hline $\begin{array}{l}4 \text { - Fundos de vale das } \\
\text { Áreas Planáltica e } \\
\text { Acidentada da cidade }\end{array}$ & - & $\begin{array}{l}\text { Sobre antiga linha de água } \\
\text { Linhas de água } \\
\text { de hierarquia } 1 \text { e } 3 \\
\text { Confluência de antigas } \\
\text { linhas de água }\end{array}$ & $\begin{array}{c}\text { Praças encaminhadoras } \\
\text { Vias paralelas às antigas } \\
\text { linhas de água }\end{array}$ \\
\hline $\begin{array}{l}5 \text { - Localizados na } \\
\text { Frente Ribeirinha }\end{array}$ & $\begin{array}{l}\text { Muito } \\
\text { elevada }\end{array}$ & $\begin{array}{c}\text { Talvegues } \\
\text { Micro-interflúvios } \\
\text { Declives fracos } \\
\text { Sector terminal da antiga } \\
\text { linha de água } \\
\text { Linhas de água } \\
\text { de hierarquia } 2 \text { e } 4\end{array}$ & $\begin{array}{c}\text { Ruas receptoras } \\
\text { Praças receptoras } \\
\text { Vias perpendiculares } \\
\text { à antiga linha de água } \\
\text { Barreiras artificiais } \\
\text { Outras áreas deprimidas } \\
\text { artificialmente }\end{array}$ \\
\hline
\end{tabular}

çada (frequência de ocorrência >80 inundações, entre 1918 e 1998) quando os lugares se localizam em áreas deprimidas, no sector terminal de antigas linhas de água, junto de barreiras artificiais e em ruas receptoras (quadro V). O declive fraco permite a acumulação das águas, oriundas das áreas mais elevadas da cidade, que chegam pelas vertentes ou pelos fundos de vale.

Embora não tenham sido estudados, os factores marinhos e as cheias do Tejo também são factores agravantes das inundações na Frente Ribeirinha, nomeadamente quando a chegada das águas a este sector da cidade coincide com situações de maré alta ou de subida da maré e/ou com situações de storm surge (sobreelevação do nível do mar de origem meteorológica), que podem provocar o "efeito de tampão» do escoamento em direcção ao Tejo. Este efeito leva ao aumento da magnitude das inundações (altura das águas) e da duração das mesmas na Frente Ribeirinha da cidade. 


\section{BIBLIOGRAFIA}

Alcoforado, M. J. (1984) - Quelques remarques sur l'évolution séculaire des précipitations à Lisbonne. In Três estudos de Geografia Física, L.A.G.F., rel. 21, CEG. Lisboa: 11- 27.

Antunes, S. (1998) - Caracterização da Variabilidade Climática Interanual em Portugal Continental. Dissertação de Mestrado, Faculdade de Ciências da Universidade de Lisboa, Lisboa.

CÂmara Municipal de Lisboa (1994) - Lisboa Ribeirinha. Pelouro da Cultura, Arquivo Municipal. Companhia Editora do Minho, Barcelos.

CÂmara Municipal de Lisboa (1997) - Lisboa e o Aqueduto. Lisboa.

Costa, P. C. (1986) - As cheias rápidas de 1967 e 1983 na região de Lisboa. In Livro de Homenagem a Mariano Feio. Lisboa: 601-616.

DiAs, M. T. (1987) - Lisboa Desaparecida, Vol. I. Quimera Editores Lda., Lisboa.

Jambu, M. (1989) - Exploration informatique et statistique des donnés. Dunod informatique Paris.

Matos, M. R. e Silva, M. H. (1986) - Estudos de precipitação com aplicação no projecto de sistemas de drenagem pluvial. Curvas de Intensidade-duração-frequência em Portugal. Laboratório Nacional de Engenharia Civil, Lisboa.

Oliveira, E. A . (1941) - Esgotos de Lisboa-Estudos de Anteprojecto. Câmara Municipal de Lisboa, Lisboa.

Oliveira, E. A . (1942) - O regime das chuvas em Lisboa. Observatório do Infante D. Luís, Lisboa.

Oliveira, P. (2002) - Inundações na cidade de Lisboa - estudo de Geografia Física. Dissertação de Mestrado, Departamento de Geografia da Faculdade de Letras da Universidade de Lisboa. Lisboa.

Proença, R. (1979) - Guia de Portugal I - Lisboa e Arredores. Fundação Calouste Gulbenkian, Lisboa.

Rebelo, F. (1997) - Risco e crise nas inundações rápidas em espaço urbano. Alguns exemplos portugueses analisados a diferentes escalas. Territorium, 4: 29-47.

ReIS, E. (1996) - Aplicação dos Sistemas de Informação Geográfica na Análise Morfométrica das Bacias Hidrográficas. Dissertação de Mestrado, Instituto Superior Técnico. Lisboa.

Ribeiro, O. (1994) - Temas Urbanos, Opúsculos Geográficos, V Volume. Fundação Calouste Gulbenkian, Lisboa.

Saraiva, M. G. e Ramos A . I. (1992) - Risco de Cheias e ordenamento do Território em Áreas Metropolitanas. Agros, 2, ISA: 24-31.

Telles, G. R. (1997) - Plano Verde de Lisboa (Componente do Plano Director Municipal de Lisboa). Edições Colibri, Lisboa.

Telhado, M. J. M. (1998) - Aplicações de sistemas de informação geográfica na análise do risco de inundação no Concelho de Lisboa. Instituto Superior Técnico, Lisboa. 
FONTES ESTATÍSTICAS, CARTOGRÁFICAS E DOCUMENTAIS

Instituto Geofísico Infante D. Luís - Anais do Instituto Geofísico Infante Dom Luís, 1918-1997. IGIDL, Lisboa.

JoRnAIS DIÁRIOS: Correio da Manhã 1979 -1992, Diário da Manhã 1931-1971, Diário de Notícias 1918 -1997, Diário Popular 1976 -1979, O Mundo 1918 - 1950, O Século 1918-1976, Público 1992-1997.

Serviço Cartográfico do Exército (1975-1981) - Carta do Concelho de Lisboa, Escala 1:10.000, fl. 1, 2, 3 e 4. SCE, Lisboa.

Serviço Nacional de Informação Geográfica - Cobertura eixos de Lisboa SNIG (2001). http://snig.cnig.pt/CommonFiles/html/info.html 